DOI: 10.34015/2523-4552.2020.1.08

УДК 343.8:159.9:316.6

Максимова Н. Ю.,

доктор психологічних наук, професор, професор кафедри соціальної реабілітації та соціальної педагогіки факультету психології Київського національного університету імені Тараса Шевченка ORCID: 0000-0003-2110-9884

Красілова Ю. М., асистент кафедри соціальної реабілітації та соціальної педагогіки факультету психології Київського національного університету імені Тараса Шевченка ORCID: 0000-0003-3758-5025

\title{
ЗАХИСТ ПРАВ НЕПОВНОЛІТНІХ ЗАСУДЖЕНИХ: РЕСОЦІАЛІЗАЦІЙНИЙ ПОТЕНЦІАЛ
}

Стаття присвячена вивченню проблеми захисту прав засуджених як основної умови їх ресоціалізації. Доведено, що ресоціалізаційний потенціал включає: високий рівень рефлексії; розвинену функцію прогнозу та цілепокладання; соціально спрямовані ціннісні орієнтації; достатній рівень суб’єктності; досягаючу мотивацію та асертивну поведінку.

Ключові слова: неповнолітні правопорушники; ресоціалізація; ресоціалізаційний потенціал; захист прав засуджених; соціальна дезадаптація.

Статья посвящена изучению проблемы защиты прав осужденных как основного условия их ресоциализации. Доказано, что ресоциализационный потенциал включает: высокий уровень рефлексии; развитую функцию прогноза и целеполагания; социально направленные ценностные ориентации; достаточный уровень субъектности; достигающую мотивацию и ассертивное поведение.

Ключевые слова: несовершеннолетние правонарушители; ресоциализация; ресоциализационный потенциал; защита прав осужденных; социальная дезадаптация.

Постановка проблеми. Гуманізація діяльності пенітенціарної системи, основою якої є захист прав засуджених має великий ресоціалізаційний потенціал. Основною детермінантою ресоціалізації $є$ бажання людини 3 девіантною поведінкою змінити себе та свої стосунки з ото- чуючими на краще. Якщо девіант вважає, що він є досконалою особистістю, а всі негаразди його життя спричинені недоброзичливістю оточуючих людей, випадковими обставинами чи іншими причинами, ресоціалізація неможлива. Особливо гостро це стосується неповнолітніх за- 
суджених. Тому, головним завданням закладів пенітенціарної системи має бути не просто виконання покарань, а турботливе керівництво розвитком особистості неповнолітнього. Забезпечення усвідомлення неповнолітнім своєї гідності, самоцінності, психологічної захищеності $\epsilon$ умовою ресоціалізації засудженого, а отже, й повернення його у суспільство, де він буде дотримуватися соціально схвалюваних норм поведінки.

Для реалізації цієї мети слід розробити форми і методи виховної роботи відповідно до типології особистості неповнолітніх засуджених. Більшість існуючих типологій базуються на констатації наявності антисуспільної спрямованості підлітка, або побудовані відповідно до мотивів злочинної поведінки, за різновидом злочину та іншими кримінально-правовими ознаками. Проте, це не дає можливості розкрити більш глибокі особистісні особливості засуджених підлітків. Відповідно до існуючих типологій не можна підібрати методи роботи, які б могли підвищити ефективність процесу ресоціалізації неповнолітніх правопорушників.

Підвищення ефективності роботи системи виконання покарань для неповнолітніх неможливо без урахування психологічних особливостей вихованців, без спрямування зусиль персоналу на перебудову світоглядних настанов вихованців, зміну ціннісних орієнтацій 3 асоціальних на соціально прийнятні. Тому актуальність психологічного дослідження процесу ресоціалізації особистості неповнолітніх засуджених не викликає сумніву для розкриття психологічних механізмів виховних впливів.
Аналіз останніх досліджень i публікацій. Існує багато трактувань поняття «ресоціалізація». Законодавство України визначає «ресоціалізацію - як свідоме відновлення засудженого в соціальному статусі повноправного члена суспільства; повернення його до самостійного загальноприйнятого соціально-нормативного життя в суспільстві» $[1$, с. 1$]$. I. I. Парфанович вважає, що «ресоціалізація має на меті перебудову особистості засудженого, його свідомості (знань, переконань, системи цінностей) та діяльності (позитивних навичок, стилю спілкування)» [2, c. 23]. На думку Т. І. Сили, ресоціалізація є складним процесом, 3 «етапами, комплексом заходів, методиками та техніками цілеспрямованого впливу який розглядається, як теоретичний концепт, та як сфера практичної діяльності» [3, с. 382].

На нашу думку найбільш вдалим $є$ таке визначення ресоціалізації: «ресоціалізація - (від лат. re - поновлення, повторення, socialis - суспільний) - це повторна соціалізація, підготовка індивіда до повернення у звичне середовище, шляхом змін цінностей, норм та установок для відновлення соціальних зв'язків. Ресоціалізація спрямована на переорієнтацію соціального спрямування

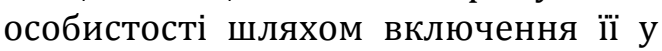
нові, позитивно орієнтовані міжособистісні стосунки та види діяльності» [4, с. 197].

Потужним соціальним фактором ресоціалізації $\epsilon$ соціальний контроль як передумова можливості здійснення психологічної корекції. Застосування різних форм соціального контролю може змінити соціальну ситуацію людини 3 девіантною поведінкою, створивши умови, за яких деві- 
ант не тільки усвідомлює свої проблеми, а й прагне їх вирішити. Більш того, соціальний контроль $є$ умовою здійснення соціально-психологічної допомоги особам з девіантною поведінкою. Він має передбачати зусилля найближчого соціального оточення, спрямовані на попередження девіантної поведінки, покарання девіантів у разі вчинення ними свідомих асоціальних дій, психологічне коригування їхньої поведінки, мотивації, ціннісної структури тощо.

Ефективне здійснення соціального контролю та застосування відповідних впливів можливе за умов, коли аналізуються не лише дії девіанта, а й його особистість та ставлення до своєї поведінки. Для цього нами була розроблена нами структура девіантної поведінки, що розкриває саме специфіку різних типів соціальної дезадаптації, дає їх якісну характеристику, розкриває їх чинники [5]. Застосування корекційних впливів, що спрямовані на детермінанти девіацій та враховують особистісні якості неповнолітніх засуджених, $є$ більш ефективним. Саме це й означає врахування психологічних факторів ресоціалізації.

Постановка завдання. Мета дослідження - розробити типологію засуджених відповідно до рівня розвитку їх ресоціалізаційного потенціалу.

Виклад основного матеріалу. У результаті нашого теоретичного дослідження ми виокремили феномен ресоціалізаційного потенціалу, в основі якого лежить здатність особистості до рефлексії. Було доведено [6], що системоутворюючим фактором процесів відновлення соціального функціонування неповнолітніх засуджених $\epsilon$ саме навичка відпові- дально ставитися до наслідків своїх дій, співвідносити свої вчинки з усвідомленням прав інших людей. Якщо ця якість у підлітка буде розвинута, то неминуче відбудеться процес каяття, який $\epsilon$ підгрунтям ресоціалізації. Складовими ресоціалізаційного потенціалу є: високий рівень рефлексії; розвинена функція прогнозу та цілепокладання; соціально спрямовані ціннісні орієнтації; достатній рівень суб'єктності; досягаюча мотивація та асертивна поведінка у ситуації фрустрації.

У загальній групі неповнолітніх із соціально дезадаптованою поведінкою потрібно виокремити групи підлітків, що $\epsilon$ справді важковиховуваними, та тих, негативні поведінкові прояви яких викликані двома іншими елементами виховного процесу - самим вихователем і характером взаємодії вихователя й вихованця. Спираючись на структуру девіантної поведінки, розроблену нами [7], було проведено емпіричне дослідження причин та поведінкових проявів засуджених відповідно до типу їх соціальної дезадаптації: соціальна дезадаптація за типом «педагогічна занедбаність»; біологічно зумовлена соціальна дезадаптація; оманлива чи ситуативно зумовлена соціальна дезадаптація; власне важковиховуваність, або особистісно зумовлена соціальна дезадаптація.

Емпірична частина дослідження відбувалась у Житомирі, Києві та Київській області (Біла Церква, Богуслав, Васильків, Іванків, Рокитне, Сквира, Фастів). Вибірка склала 60 неповнолітніх, засуджених до покарань, не пов'язаних з позбавленням волі.

У результаті нашого дослідження ми виокремили шість типів 
неповнолітніх правопорушників (Рис. 1), а саме: імпульсивні; асоціально спрямовані; особистісно незрілі; особистісно зумовлені; ситуатив- ні; контекст залежні. Слід підкреслити, що серед неповнолітніх засуджених зазначені різновиди розподілилися нерівномірно (Див. Рис. 1).

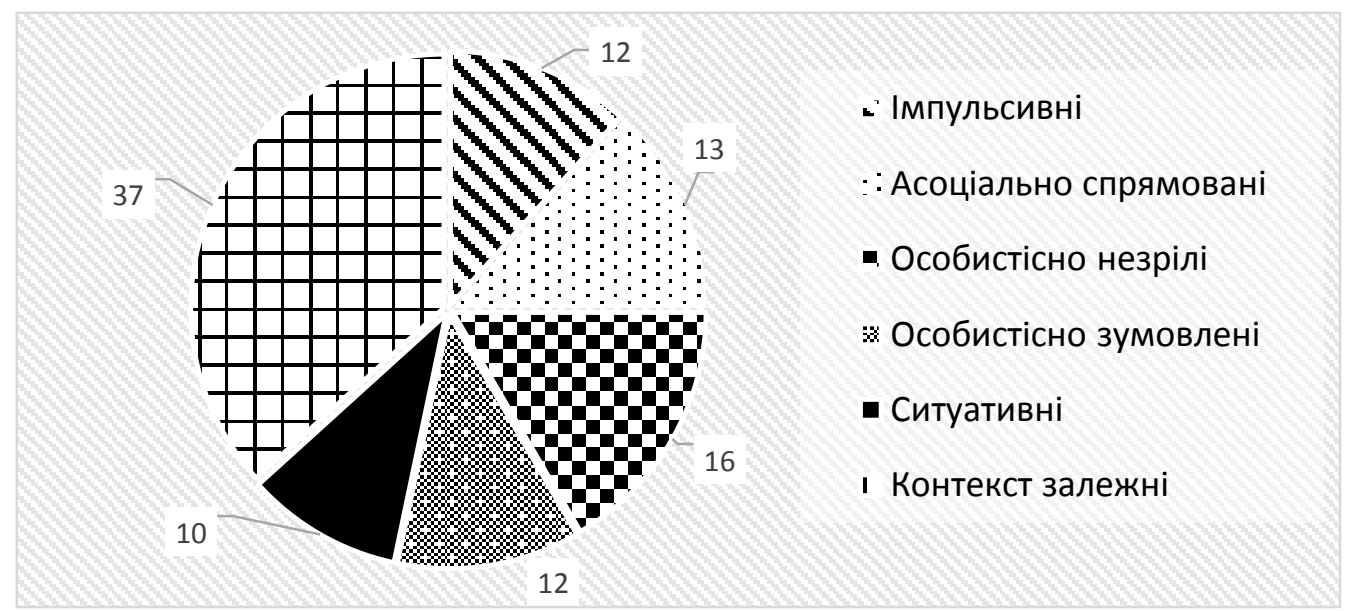

Рис.1. Типологія неповнолітніх засуджених (\%)

Розглянемо вищезазначену типологію відповідно до системоутворюючих факторів. До імпульсивних ми віднесли неповнолітніх правопорушників, які не вміють прогнозувати свої вчинки, а тим більше їх наслідки. Імпульсивні підлітки діють не роздумуючи, процес свідомого прийняття рішення у них практично відсутній. Вони мають низький рівень розвитку рефлексії.

У підлітків даного типу переважають ціннісні орієнтації егоїстичного спрямування. В уявленнях про майбутнє вони не відчувають себе суб'єктами своєї діяльності; їм притаманна уникаюча мотивація; у фруструючих ситуаціях їх реакція - агресивна.

Асоціально спрямовані. Це підлітки, які мають асоціальні цінності та вороже ставляться до суспільства. Вони мають егоїстичну спрямованість, при цьому відчувають себе суб'єктами власної діяльності, але в разі наявності перешкод (фруструючих ситуацій) діють агресивно. Підлітки, яких ми віднесли до цього типу, мають низький рівень рефлексії, недосконалий рівень функції прогнозу та уникаючу мотивацію.

До особистісно незрілих ми віднесли підлітків, які не мають чітких моральних уявлень, вони не засвоїли норм соціально прийнятної поведінки. Як і імпульсивні, вони мають низький рівень розвитку рефлексії. Оскільки у них не розвинена функція цілепокладання та функція прогнозу, такі підлітки взагалі не усвідомлюють себе суб'єктами власної діяльності. Разом з цим в ситуації фрустрації вони поводять себе не агресивно, їх поведінка не асертивна та суперечлива.

Особистісно зумовлені неповнолітні засуджені. Системоутворюючим фактором $\epsilon$ вороже ставлення до світу. Зважаючи на наші попередні дослідження [5] підлітки цього типу, 
мають неадекватну самооцінку, через те, що вони перебувають у внутрішньому конфлікті. Варто зазначити, що підлітки, які відносяться до цього типу, мають мотивацію досягнення, проте, функція прогнозу на недосконалому рівні, рівень рефлексії низький, що пов'язано з їх життєвою ситуацією на момент обстеження.

Підлітки, яких ми віднесли до ситуативних, не мають відхилень у розвитку особистості. Такі підлітки можуть скоїти злочин лише в тому випадку, якщо ситуація, в якій вони опинилися, перевищила їх можливості розуміння того, що відбувається. Як правило це була ситуація життевої кризи. До цього типу можна віднести тих підлітків, які скоїли злочин один раз. У підлітків даного типу соціально спрямовані ціннісні орієнтації, вони добре усвідомлюють себе суб'єктом власної діяльності. Вони мають розвинену функцію прогнозу та високий рівень рефлексії.

Контекст залежні засуджені це насамперед особи, які не відчувають себе суб'єктом своєї діяльності. Такий підліток поводить себе в залежності від контексту, до якого він включений. Ця особа прагне постійно перебувати в групі, оскільки самостійно не може прийняти рішення, а приналежність до групи додає сил i впевненості.

По результатах дослідження, функція прогнозу та цілепокладання у цієї категорії осіб на низькому рівні, а у деяких випадках навіть зовсім відсутня. У переважної більшості неповнолітніх, яких ми віднесли до цієї групи, переважає недосконалий рівень усвідомлення життєвої перспективи, вони не планують своє майбутнє.
Отже, необхідно зробити кардинальні зміни у підходах до ресоціалізації неповнолітніх правопорушників, які потрібні для того, щоб реформувати пенітенціарну систему відповідно до міжнародних стандартів. Відповідно до цих стандартів неповнолітнього рекомендується направляти до виправного закладу тільки в разі крайньої міри і протягом мінімально необхідного строку. Пекінські правила рекомендують створення можливості такого розгляду справ за наявності програм у рамках громади, які забезпечують нагляд, керівництво, відшкодування шкоди потерпілому. Якщо ж неповнолітній у силу визнання його винним у скоєнні серйозного злочину або неодноразового здійснення інших порушень усе ж потрапив за грати, то необхідно докласти зусиль для його виправлення в якомога більш короткі строки і направлення на умовне визволення. Застосування зазначених правил потребує широкої участі різних органів і організацій, які мають працювати в таких напряMax:

- необхідність забезпечення громадського порядку й суспільної безпеки, захисту потенційних жертв правопорушень, які вчиняють неповнолітні. При цьому вік правопорушника має велике значення для фахівців і представників громадськості, зокрема, одним 3 основоположних принципів Ер-Ріядських правил $\epsilon$ необхідність урахування того, що вчинки молодих людей або їх поведінка, що не відповідає соціальним нормам, у багатьох випадках пов язані з процесом дорослішання і по мірі зростання, їх поведінка може змінитися на краще без втручання правоохоронних органів; 
- потреба в тому, щоб кожний, хто скоїв правопорушення, отримав за це покарання; саме невідворотність, а не суворість покарання, має бути основним принципом порядку в суспільстві;

- турбота про те, щоб кожний неповнолітній, який скоїв злочин, мав можливість отримати індивідуальний підхід, необхідний саме йому для того, щоб запобігти (знизити ймовірність) можливості скоєння нових правопорушень.

На сьогодні в Україні застосування покарань у вигляді позбавлення волі вже не $\epsilon$ розповсюдженим щодо неповнолітніх. Разом 3 цим, слід чітко усвідомлювати, що позбавлення волі вже само по собі $є$ психотравмуючим фактором, тому решту обставин перебування неповнолітніх у колонії необхідно змінити таким чином, щоб це позитивно впливало на особистість засуджених. Якщо цього не зробити, то наявність соціальної депривації настільки негативно впливає на ситуацію розвитку особистості, що призводить до фіксації особистісних відхилень, викликає ще більше відчуження засуджених від суспільства, їх ціннісні орієнтації стають у все більшу конфронтацію 3 моральними нормами, що спричинює ненависть до структур влади (поліції, суду, прокуратури тощо) і взагалі до всіх законослухняних громадян. У зв`язку з цим необхідно розробити нові підходи до роботи, визначити методологічні трансформації, а головне - увести диференціацію відповідно до типу соціальної дезадаптації правопорушника.

На чолі вирішення цих завдань повинна бути принципово нова функціональна модель ювенального виправного центру Державної пенітен- ціарної служби. До речі, ідея створення ювенальних виправних центрів в Україні була підтримана Бюро співпраці Європейської комісії в Україні. Реформування діяльності закладів для неповнолітніх потребує таких заходів:

1) Організація під егідою Національної академії педагогічних наук України міжвідомчої наукової робочої групи для проведення широкого дослідження проблеми і вироблення комплексних пропозицій щодо правових, педагогічних, соціальних i економічних передумов створення моделі ювенального виправного центру.

2) Створення законодавчих i організаційних передумов функціонування ювенальних виправних центрів шляхом аналізу, унесення необхідних змін і доповнень до чинного законодавства.

3) Розробка пропозицій щодо вирішення задач формування нового архітектурного середовища ювенальних виправних центрів 3 урахуванням комплексного і середовищного підходу до організації належних умов життєдіяльності дітей, які в них утримуються, навчально-виховного процесу та ефективної соціальної реабілітації.

4) Розробка, державне ліцензування і впровадження на базі ювенальних виправних центрів спеціальних взаємопов`язаних програм, які б ураховували особливості соціального, психологічного і фізіологічного розвитку кожної дитини. Під час перебування неповнолітнього у виправному центрі необхідно створити умови для трудотерапії, навчання соціальним навичкам, розвитку позитивних особистісних рис дітей, засвоєння шкільного курсу відповід- 
но до віку та з урахуванням необхідності ліквідації прогалин у знаннях. Важливою складовою процесу ресоціалізації $\epsilon$ надання можливості неповнолітньому відчути себе суб`єктом своєї життєдіяльності, тобто надавати йому можливості зробити правильний власний вибір у різних життєвих ситуаціях.

5) Важливим моментом $є$ кадрове забезпечення діяльності ювенальних виправних центрів. Тут насамперед слід зазначити, що специфіка роботи з неповнолітніми правопорушниками потребує спеціальної підготовки фахівців, яка, на жаль, зараз відсутня.

Висновки. Забезпечення захисту прав неповнолітніх засуджених передбачає впровадження нових методів реабілітаційної роботи та зміну всього спектру умов - економічних, правових, педагогічних, соціальних, організаційних і відносин між суб єктами суспільного життя. Основною базою для виконання цієї мети є: розробка науково обгрунтованих рекомендацій щодо нових теоретичних, методологічних і аксіологічних установок, які відповідають меті якнайкращого забезпечення інтересів дітей, які перебувають у конфлікті із законом; використання найкращого світового наукового і практичного досвіду у галузі захисту прав дітей.

\section{Перспективи дослідження} полягають у розробці психологічних аспектів ювенальної юстиції в Україні, що відкриває можливості для ресоціалізації неповнолітніх засуджених та профілактики злочинності.

\section{Список використаних джерел}

1. Кримінально-виконавчий кодекс України. Відомості Верховної Ради України (ВВР), 2004, № 3-4, ст. 21. URL: https://zakon.rada.gov.ua/laws/show/1129-15 (дата звернення: 13.02.2020).

2. Парфанович I. І. Система виховної роботи з умовно засудженими неповнолітніми : навч. посіб. Тернопіль : ТИПУ, 2005. С. 176.

3. Сила Т. І. Міждисциплінарний зміст поняття «ресоціалізація». Збірник наукових праць Інституту психології імені Г. С. Костюка НАПН України. Київ, 2011. Т. XIII. Ч. 1. С. $382-389$.

4. Лютий В. П. Ресоціалізація неповнолітніх, звільнених від відбування покарання з випробуванням. Теоретико-методичні проблеми виховання дітей та учнівської молоді : зб. наук. пр. Т.12. 2008. С. 197-204.

5. Максимова Н. Ю. Соціально-психологічні аспекти гуманізації судочинства та кримінально-виконавчої системи. Київ : ЗАТ «Віпол», 2005. 100 с.

6. Красілова Ю. М. Ціннісні орієнтації, цілепокладання та функція прогнозу підлітків-правопорушників. Science and Education a New Dimension. Pedagogy and Psychology, V (60), Issue : 135, 2017. Будапешт. C. 72-75.

7. Максимова Н. Ю. Психологія девіантної поведінки : навч. посіб. Київ : Либідь, 2011. 520 с.

\section{References}

Parfanovych, I. I. (2005). Systema vykhovnoi roboty z umovno zasudzhenymy nepovnolitnimy. Ternopil: TYPU [in Ukrainian].

Syla, T. I. (2011). Mizhdystsyplinarnyi zmist poniattia «resotsializatsiia». Zbirnyk naukovykh prats Instytutu psykholohii imeni H.S. Kostiuka NAPN Ukrainy. Kyiv, T. XIII, 1, 382-389 [in Ukrainian].

(C) Максимова Н. Ю., Красілова Ю. М., 2020 
Liutyi, V. P. (2008). Resotsializatsiia nepovnolitnikh, zvilnenykh vid vidbuvannia pokarannia $\mathrm{z}$ vyprobuvanniam. Teoretyko-metodychni problemy vykhovannia ditei ta uchnivskoi molodi : zb. nauk. pr., 12, 197-204 [in Ukrainian].

Maksymova, N. Yu. (2005). Sotsialno-psykholohichni aspekty humanizatsii sudochynstva ta kryminalno-vykonavchoi systemy. Kyiv: ZAT «Vipol» [in Ukrainian].

Krasilova, Yu. M. (2017). Value orientations, goal setting, and the prediction function of delinquent adolescents. Science and Education a New Dimension.Pedagogy and Psychology, V (60), Issue: 135, 72-75 [in Hungarian].

Maksymova, N. Yu. (2011). Psykholohiia deviantnoi povedinky. Kyiv: Lybid [in Ukrainian].

N. Maksymova, Doctor of Psychology, Professor of the Department of Social Rehabilitation and Social Pedagogy in the Taras Shevchenko National University of Kyiv ORCID: 0000-0003-2110-9884

Y.Krasilova, Assistant of the Department of Social Rehabilitation and Social Pedagogy in the Taras Shevchenko National University of Kyiv

e-mail: k-j-m@ukr.net; ORCID: 0000-0003-3758-5025

\section{Juvenile defence of rights: re-socialisation potential}

The article is devoted to the study of the problem of defence of rights of convicted as a main condition for their re-socialization. It is shown that the feeling of insecurity leads to the fixation of personal deviations, it causes even more alienation of convicted from society, their value orientations stay more and more in confrontation with moral standards, that causes hatred for the power authorities and for all law-abiding citizens in general. Purpose of the study: to design a typology of convicted persons according to the level of development of their re-socialization potential.

The components assuring the process of re-socialization are the following: finding out the causes and factors of violations of social requirements, rules and laws, their singleness or recurrence; determination of the person's attitude to social norms, requirements and to own behaviour; identifying the incentives to be applied for the purpose of correction and necessary sanctions provided for in case of a deviant's refusal to comply with the social norms; the existence of public institutions, organizations, establishments that fulfill the socializing influence; sociopsychological prognosis of the further life course of a person with deviant behaviour.

It is proved that re-socialization potential includes: a high level of reflection; developed functions of forecasting and goal setting; socially oriented system of values; a sufficient level of subjectivity; attaining motivation and assertive behaviour in a frustration situation. The systemic factor of the processes of renewal of social functioning of juvenile convicted is the skill to responsibly treat the consequences of their actions, to correlate their actions with the awareness of other people's rights. If this quality is developed in a teenager, then the process of repentance, which is the basis of re-socialisation, will inevitably occur. 
The typology of juvenile offenders has been developed: impulsive; socially focused; personally immature; personally conditioned; situational; dependent on context. The algorithm of activity of specialists of the penitentiary system for ensuring defence of the rights of juvenile convicted is presented.

Keywords: juvenile offenders; re-socialisation; re-socialisation potential; defence of rights of convicted; failure in social endeavours. 